\title{
DEVELOPMENT OF NEW METHOD OF DRYING AT ENERGY-SAVING UNIVERSAL DRYER TO IMPROVE QUALITY OF CROPS USED IN FODDER PRODUCTION
}

\author{
Artem Kliuchnikov \\ Yaroslavl Scientific Research Institute of Livestock Breeding and Forage Production - Federal State \\ Budget Scientific Institution Federal Williams Research Centre of Forage Production and \\ Agroecology, Russia \\ artik8487@mail.ru
}

\begin{abstract}
A new universal method of efficient, low temperature, convective drying has been developed, which allows drying seed, ground mass of grain, leguminous, fodder and industrial crops, as well as flax straw, flax and wood sawn to obtain finished products of high quality and reduce energy consumption for moisture removal. Fuller realization of the advantages of the new method required the development of a new dryer. The process of drying material is carried out in a motionless layer. The uniformity of drying on the area of the drying chamber is provided with a wedge form of channels for supply of the drying agent, which expense on the entrance is regulated at louver valves and also at each channel an air distributing grid with adjustable coefficient of equipotential section. The uniformity of drying on the height of a layer of material is provided with reversal of the direction of the movement of the drying agent in the middle of the drying process. Automation of the process of drying is based on constant control of the mass of material in the drying chamber. Tests of the dryer are carried out under production conditions. Drying was conducted in the new way of seed heap of grain crops and chopped grass mass of clover. The results showed that the commercially available drier energy consumption for the drying process is higher than $30 \%$. The actual heat consumption for removal of one kilogram of moisture from wheat grain with an initial moisture content of $24.7 \%$ to a moisture content of $13.5 \%$ was 3.5 MJ. The seeds of cereal crops, which are dried in the new method after cleaning and sorting, had viability, energy of germination and seedling up to $98 \%$.
\end{abstract}

Keywords: drying, automatic universal dryer, convective drying technology.

\section{Introduction}

Convection drying of agricultural materials is energy consuming. Therefore, improvement in the efficiency of the process, including high quality of dry seeds at the lowest possible energy consumption, is essential for agriculture. Numerous studies have been conducted to date to determine the convection drying conditions ensuring satisfactory parameters of energy saving. Markowski et al determine the best energy performance for Combined IR-Convection Dryers (temperature and speed of the drying agent) [1]. Tsyvenkova $\mathrm{N}$. et al showed that using generative gas and straw as fuel can reduce the energy consumption for the drying process in a fluid-bed dryer by $10-30 \%$ [2]. Hemisa et al have shown that the use of simultaneous MW and convective drying to wheat seeds can increase the drying speed, but the percentage of wheat seed germination decreases with increasing the power megawatts [3].

The most important criteria for seeds used in production quality determination include vitality (germination energy and capacity), enzymatic activity, protein content and resistance to microbiological contamination. The quality of seeds strongly depends on the history of changes in their temperatures, rates of their drying during thermal processing and the degree of injury to the seed during the drying process. The most optimal conditions for obtaining high-quality seeds are provided in the process of drying in a fixed bed with a minimum quantity of movements.

It should be noted that in order to increase the profitability of agricultural production as a whole, it is necessary to increase the coefficient of annual loading of drying equipment, since today the majority of grain dryers are used about 40 days a year.

Many researchers have shown that using the convective method of drying various crop production can be effectively dried: potatoes slices, carrot slices, green mass of medicinal plants and plants used as biofuel [4-7]. Therefore, the priority now is creation of energy-efficient and versatile drying equipment. This equipment will allow to obtain high quality seed material and provide a high annual load factor due to the possibility of drying various crop production.

To solve the problems posed by the authors, a new energy-efficient, three-stage, convective drying method in stationary state was developed. To implement the new method a new US- 0.35 dryer was developed and manufactured [8;9]. The objective of this research is to test under production 
conditions the new method and dryer for further introduction in the line of post-harvest processing of field crops.

\section{Materials and methods}

The method of effective, low-temperature, convective drying has the following advantages: versatility, energy efficiency, high uniformity of drying. High quality indicators of the finished dried material are achieved by drying in one load, without transshipments and expensive intermediate operations.

The new method includes three stages: 1 - step-by-step increase in the temperature of the drying agent from its value in the environment to one selected value from the range of $30 \ldots 60{ }^{\circ} \mathrm{C} ; 2$ - time constant temperature of the drying agent. In the middle of the stage, the direction of movement of the drying agent is reversed; 3 - step-by-step decrease in the temperature of the drying agent to its value in the environment [8].

Modular construction of the dryer, in which the new way is implemented, easily fits into the product line of different productivity. According to the data on the moisture and contamination of the grain pile entering drying in the North-West region, the productivity of the base and mini-module of the new dryer was justified by the finished dried grain of wheat. A mini-module of the universal dryer US- 0.35 with a capacity of 0.35 tons per hour was designed and built [10]. US-0.35 is intended for production of dry grass food, drying lots or crushed grain, leguminous, fodder and industrial crops, as well as flax, flax straw and sawn timber [9].

The test of the dryer US-0.35 was carried out in accordance with GOST R55262-2012. The test was conducted on a grain heap of wheat varieties "Sudarynya", winter rye varieties "Tatyana" and chopped grass mass of clover varieties Konischevsky. During the test, the following parameters were monitored: temperature of the drying agent is $t_{\text {d.a. }},{ }^{\circ} \mathrm{C}$ (controlled with a Testo 435 plus probe with a heated flow thread); consumption of the drying agent $Q_{\text {d.a. }}\left(\mathrm{m}^{3} \cdot \mathrm{s}^{-1}\right)$ was set to the maximum, but providing the most complete testing of the drying agent in a single pass through the drying material (measured indirectly using a Testo 435 plus probe with a heated flow thread). The output indicators were: capacity of the dryer $\mathrm{G}$, tons per hour, calculated according to indications of the automated weighing system "Happy Feeder III" that is designed for the shredder mixer feed distributor ISRK-12 (LLC "ZAPAGROMASH"); power consumption of electricity is $\mathrm{N}, \mathrm{kW} \cdot \mathrm{h}^{-1}$, determined by the electricity meter "Mercury - 230 ART 03"; temperature of the spent drying agent $t_{\text {s.d.a. }}{ }^{\circ} \mathrm{C}$ and the humidity of the spent drying agent $\varphi_{\text {s.d.a. }} \%$ were determined with a Testo 435 plus probe with a heated flow thread; consumption of the spent drying agent $Q_{\text {s.d.a. }} . \mathrm{m}^{3} / \mathrm{s}$, was calculated indirectly by the method in accordance with GOST R 55262-2012 (STO AIST 10.2-2010) using a Testo 435 plus device with a heated thread probe; moisture content of the material after drying $\omega^{a}{ }_{m}, \%$ was determined by the method of GOST 12041-82 in a drying cabinet; temperature of the material at the outlet of the dryer $t_{\text {m.a. }},{ }^{\circ} \mathrm{C}$ was determined using a pyrometer and a mercury thermometer (GOST R 55262-2012). The value of the following parameters affects the operation of the dryer: atmospheric pressure $\mathrm{P}, \mathrm{Pa}$, determined using an aneroid barometer; $t_{0},{ }^{\circ} \mathrm{C}$, and humidity $\varphi_{\mathrm{o}}, \%$, of outside air were measured with a Testo 435 plus probe with a heated flow thread; initial mass of the material in the dryer $G_{1}, \mathrm{~kg}$ was determined using an automated weighing system; initial humidity of the received batch of material is $\omega_{m}^{i}$, \%; material temperature at the entrance to the dryer is $t_{\text {m.e. }}{ }^{\circ} \mathrm{C}$.

To test the hypothesis of high values of the quality of dried-up seeds, laboratory tests for germination and seed germination energy (GOST 12036-85, GOST 12038-84) were conducted after testing according to standard methods.

\section{Results and discussion}

The dryer US- 0,35 works as follows. Before drying, the rail guides 29 are fixed from the air distribution grilles 2 at such a height that ensures the optimum thickness of the drying material to be loaded. The upper exhaust fan 12 is connected to the diffuser 7, the rotary pipe 9 is attached to the lower diffuser. A heap or crushed material loaded in the tray 31 is sent to the drying chamber 1 by the screws 20 and 21. During the loading process, when the sensor 28 is triggered from contact with wet material at the front wall of the dryer, the controlled coupling 26 activates the gear motor 27 , which rotates the screw 25 . The nut 24 in the coulisse 23 transfers the trolley conveyor 22 and the loading 
tray 31 at a fixed distance in the transverse direction of the chamber 1 for a phased loading with the same material layer height along the entire chamber area. Upon completion of loading, the limit switches 30 turn off the gear motor 27 and the augers 20 and 21. The process of filling the drying chamber 1 with the material is controlled visually through viewing windows 35 , which are made on both sides. Automated weighing system 16 is transferred from the lock to the automatic mode. The flow rate of the drying agent depending on the desired drying mode is set by changing the position of the flaps 8 and carriages 3, in which the sliders 4 are moved by the levers 5 . The fans 10 and 12 are activated and then the electric air heater 11. The drying agent enters the diffuser 7 and the air inlet channel 6 through the openings 39 of the air distribution grids 2 into the drying material. Grids 2 change the direction of the drying agent from horizontal to vertical $\left(90^{\circ}\right)$. The wedge shape of the channel 6 ensures uniform distribution of the drying agent along the length of the drying chamber 1 , since the speed of the movement of the drying agent in all holes 39 is the same. The uniform distribution of the drying agent over the area and volume of the drying chamber is controlled by turning on / off one of the two fans 10, changing the rotational speed of the second fan 10, dampers 8 , carriages 3 with levers 5 and the layer thickness of the drying material (Fig. 1).

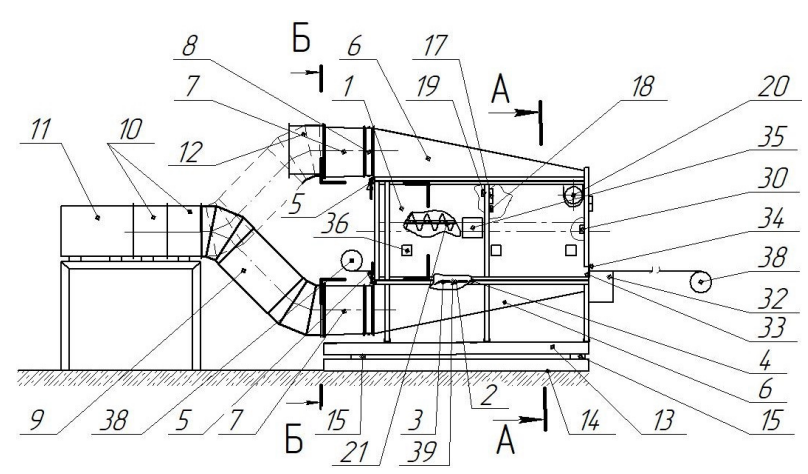

a)

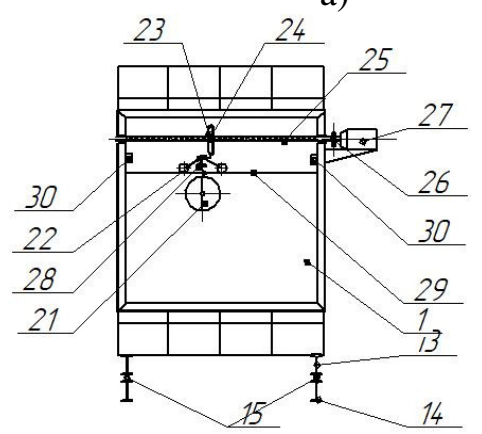

c)

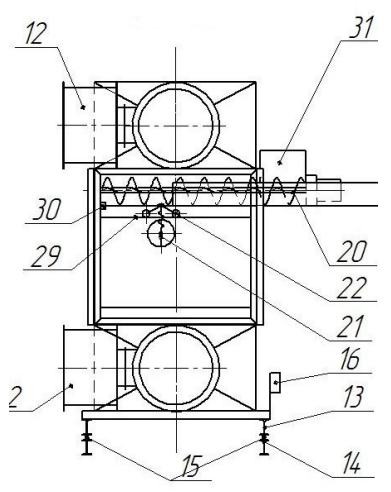

b)

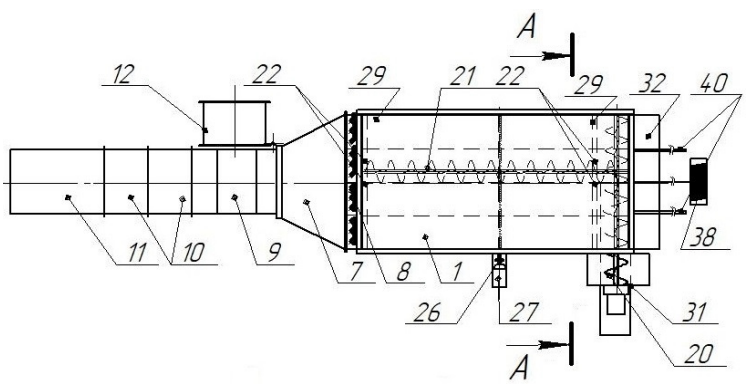

d)

Fig. 1. Dryer US-0.35 - general side view (a), cross section along A-A (b), the mechanism for moving the carriage conveyor, a cross-section along B-B (c), a view of the US-0.35 dryer above

(d): 1 - camera; 2 - airdistributing grid; 3 - carriage; 4 - slider; 5 - lever; 6 - airsupply canal;

7 - diffuser; 8 - louver; 9 - pipe; 10 - fan; 11 - electric air heater; 12 - upper and lower fans;

13 - frame; 14 - subframe; 15 - strain gauge sensors; 16 - weighing system; 17 - relative humidity sensors; 18 - temperature sensors; 19 - movement speed sensors; 20 - transverse auger;

21 - longitudinal screw; 22 - conveyor; 23 - coulisse; 24 - nut; 25 - screw; 26 - clutch; 27 - gear motor; 28 - level sensor; 29 - guide rail; 30 - limit switches; 31 - loading tray; 32 - shipping tray;

33 - unloading window; 34 - valve; 35 - viewing window; 36 - sampler; 38 - electric winch; 39 - openings of air distribution grids $2 ; 40$ - rail track

At the first stage, the drying material is gradually heated by incrementally increasing the temperature of the drying agent. Heats up to the temperature chosen for this material $30 \ldots 60^{\circ} \mathrm{C}$. The exhaust fan 12 directs the spent drying agent to the outside. Control and optimization of the drying process is provided by a programmable microcontroller. It receives information about the drying process from the sensors $17,18,19$ together with an automated weighing system 16 . The selected optimal temperature of the drying agent during the second stage is not changed. In the middle of 
drying, it is determined by the display of the automated weighing system 16 , changing the direction of the movement of the drying agent to the opposite to obtain the same final moisture content of the drying material. The fans 10,12 and the electric heater 11 are disconnected. At the hinges, the upper exhaust fan 12 is turned to the side. The pipe 9 is connected to the upper diffuser 7 , and the exhaust fan 12 is turned and fixed to the lower diffuser 7 by turning on the fans 10,12 and the electric air heater 11 at the selected temperature of the drying agent of the second stage of drying. At the third stage of drying, which is equal to the first one in time, stepwise reduction of the temperature of the drying agent to ambient temperature is conducted. Any source material is dried in one load without unnecessary transshipment and expensive intermediate operations: cooling, moistening, conditioning, thermomoisture processing.

As soon as the drying material reaches the standard humidity, which is determined by the display of the automated weighing system 16, the electrical load air heaters 11 and 12 are disconnected from the strain gauge sensors 15 located between the frame 13 and the subframe 14 . At the hinges, the lower exhaust fan 12 is turned to the side, the rotary pipe 9 is connected to the lower diffuser, and the exhaust fan 12 is turned and fixed to the upper diffuser. The fans 10 are turned on and the unheated ambient air is fed alternately through one channel 6 into the chamber 1 . The air is coming out from the air distribution grid 2, further cooling and unloading of the dried material are performed through the window 33 opened by the valve 34, to the shipping tray 32 . At the end of unloading 34 windows 33 close the valve. The augers 20 and 21 form a new even specified layer of raw material in the chamber 1 , and then turn on the fans 10,12 and the furnace unit 11 to continue drying the newly-loaded wet material.

Removing moisture from the surface of the material, which is washed by the drying agent, occurs at any temperature in the range of 0 to $100{ }^{\circ} \mathrm{C}$, but with a constant specific heat supply of at least $2260 \mathrm{~kJ} / \mathrm{kg}$. Therefore, it is a more profitable way to dry at low temperatures, reducing the cost of heating the material. Previously obtained results of the study of the process of drying sawn timber of wood showed that increasing the temperature of the drying agent from $40{ }^{\circ} \mathrm{C}$ to $100{ }^{\circ} \mathrm{C}$ increases the specific energy consumption from 2900 to $4300 \mathrm{~kJ} / \mathrm{kg}$ of evaporated moisture, or $48 \%$. The increase in the specific energy consumption is associated with a decrease in the heat transfer coefficient $\mathrm{K}$ to 2,5 times. The coefficient of heat transfer To determines:

$$
K=\frac{q}{\Delta T},
$$

where $q$ - the energy flux density;

$\Delta T$ - the temperature difference between the medium of the drying agent and the surface of the material.

Therefore, if the difference of temperatures of the drying agent and material of drying is less, the heat transfer coefficient is higher.

When developing a new way of drying, it is considered that the movement of moisture from inside layers of material, which is the isotropic environment, defines the law of Fourier, according to which the vector of heat flux density is proportional and opposite in the direction to a temperature gradient of outside and inside layers of material. Therefore, smooth accumulation of temperature of the drying agent minimizes counteraction of moisture to the movement in separateness of material to a surface. Therefore, energy costs of the specified counteraction are minimized.

In the course of drying at a high continuous temperature of the drying agent, in the process of approach of humidity of material to critical, the evaporation zone begins with a surface of separateness of material to go deep inside [11]. It is connected with the difference of speeds of evaporation and the supply of moisture to the surface. When drying-up seeds, this effect leads to thermal damage of a cover and subsurface layer of a seed. Drying material heating over $70{ }^{\circ} \mathrm{C}$ starts the Maynard's reaction that negatively affects the quality of the dried-up product [12]. The new way of drying is deprived of these shortcomings. At the third stage of drying the temperature of the outside layers of separateness of material begins to decrease. The direction of the moisture movement as a result of the temperature and humidity gradients occurring coincide towards the surface of the material. As a result, the rate of 
evaporation of moisture from the surface of the drying material is equal to the rate of supply of moisture from its inner layers

Studies on US-0.35 on the effect of the drying method on the indicators of the drying process under comparable conditions allow us to conclude that energy costs for heating the drying agent are reduced by $15 \%$, at a maximum drying agent temperature of $35^{\circ} \mathrm{C}$ (Fig. 2). These graphs are given as one of many according to the results of our research. The drying time in both ways is almost the same. The area of the shaded triangles is equal to the power savings on heating the drying agent. It should be noted that the temperature of the grain after drying with the new method does not exceed the ambient temperature by more than $50^{\circ} \mathrm{C}$, which corresponds to the agrotechnical requirements. The grain after drying at a constant temperature of the drying agent requires an additional cooling operation.

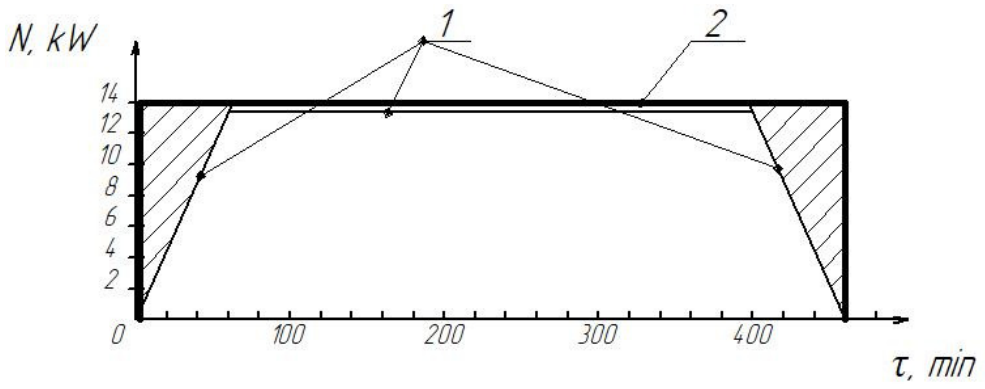

Fig. 2. Effect of drying time $\tau$ on power consumption $\boldsymbol{N}$ for heating drying agent:

1 - using the new drying method; 2 - according to the existing method

Studies have been conducted on the new drying method for US-0.35 with various drying materials. For example, the heat consumption for removing $1 \mathrm{~kg}$ of moisture for a grain heap of wheat with an initial moisture content of $24.7 \%$ was $3.5 \mathrm{MJ} \cdot \mathrm{kg}^{-1}$ moisture. This indicator for the common in Russia DSP-32 dryer is about $4.5 \mathrm{MJ}$, which is $28 \%$ higher than the US-0.35 dryer [13]. Heat consumption for removing $1 \mathrm{~kg}$ of moisture from crushed herbal mass of clover with a humidity of $77 \%$ was $3.12 \mathrm{MJ} \cdot \mathrm{kg}^{-1}$ moisture. For the AVM-1.5G dryers widely used in Russia for drying crushed herbal mass, the heat consumption for removing $1 \mathrm{~kg}$ of moisture is $4.05 \mathrm{MJ}$, which is $30 \%$ higher than for the US-0.35 dryer [14].

As a result of testing US-0.35 under production conditions, when drying a grain heap of wheat, rye and crushed clover mass, data were obtained, based on which the technical and energy indicators of a US- 0.35 dryer were determined (Table 1). The calculation was made in accordance with GOST R 55262-2012.

Table 1

Characteristics of the parameters affecting the operation of the dryer during testing, technical and energy performance of the dryer US-0.35

\begin{tabular}{|c|c|c|c|c|}
\hline \multirow{2}{*}{ Indicator } & \multicolumn{4}{|c|}{ Value } \\
\cline { 2 - 5 } & $\begin{array}{c}\text { Wheat } \\
\text { new method } \\
(M \pm m)\end{array}$ & $\begin{array}{c}\text { Rye } \\
\text { existing } \\
\text { method } \\
(M \pm m)\end{array}$ & $\begin{array}{c}\text { Rye } \\
\text { new method } \\
(M \pm m)\end{array}$ & $\begin{array}{c}\text { Clover } \\
\text { new method } \\
(M \pm m)\end{array}$ \\
\hline Atmospheric pressure $P, \mathrm{kPa}$ & $101.1 \pm 0.05$ & $101.1 \pm 0.02$ & $99.5 \pm 0.14$ & $101.14 \pm 0.03$ \\
\hline Outdoor temperature $t_{\mathrm{o} .},{ }^{\circ} \mathrm{C}$ & $10.2 \pm 0.15$ & $12.8 \pm 0.83$ & $14.4 \pm 0.27$ & $14.8 \pm 0.15$ \\
\hline Outside air humidity $\varphi_{\text {o. }}, \%$ & $67 \pm 0.12$ & $60 \pm 0.14$ & $70 \pm 0.42$ & $77 \pm 0.46$ \\
\hline $\begin{array}{c}\text { Initial mass of material in the } \\
\text { dryer, } G_{1}, \mathrm{~kg}\end{array}$ & $1070 \pm 0.05$ & $918.2 \pm 0.08$ & $982.3 \pm 0.10$ & $195.3 \pm 0.05$ \\
\hline $\begin{array}{c}\text { Moisture content of the } \\
\text { incoming material } \omega^{i}, \%\end{array}$ & $24.7 \pm 0.06$ & $21.5 \pm 0.11$ & $20.2 \pm 0.12$ & $67.7 \pm 0.24$ \\
\hline $\begin{array}{c}\text { Temperature of the material at } \\
\text { the entrance to the dryer } t_{\text {m.e. }},{ }^{\circ} \mathrm{C}\end{array}$ & $14.0 \pm 0.05$ & $13.5 \pm 0.06$ & $16 \pm 0.06$ & $15 \pm 0.04$ \\
\hline $\begin{array}{c}\text { Maximum temperature of the } \\
\text { drying agent } t_{\text {d.a. }},{ }^{\circ} \mathrm{C}\end{array}$ & $30 \pm 0.05$ & $32 \pm 0.05$ & $36 \pm 0.05$ & $23.6 \pm 0.05$ \\
\hline
\end{tabular}


Table 1 (continued)

\begin{tabular}{|c|c|c|c|c|}
\hline \multirow[b]{2}{*}{ Indicator } & \multicolumn{4}{|c|}{ Value } \\
\hline & $\begin{array}{c}\text { Wheat } \\
\text { new method } \\
(M \pm m)\end{array}$ & $\begin{array}{c}\text { Rye } \\
\text { existing } \\
\text { method } \\
(M \pm m)\end{array}$ & $\begin{array}{c}\text { Rye } \\
\text { new method } \\
(M \pm m)\end{array}$ & $\begin{array}{c}\text { Clover } \\
\text { new method } \\
(M \pm m)\end{array}$ \\
\hline $\begin{array}{l}\text { Temperature of the material } \\
\text { after drying } t_{m}{ }^{\circ} \mathrm{C}\end{array}$ & $15 \pm 0.06$ & $22 \pm 0.06$ & $19 \pm 0.05$ & $17 \pm 0.06$ \\
\hline $\begin{array}{l}\text { Moisture content after drying } \\
\qquad \omega_{a}^{m}, \%\end{array}$ & $13,5 \pm 0.07$ & $13,5 \pm 0.09$ & $13,5 \pm 0,06$ & $11 \pm 0.09$ \\
\hline $\begin{array}{l}\text { Productivity of the dryer } G, \text { tons } \\
\text { per hour }\end{array}$ & $0.065 \pm 0.09$ & $0.11 \pm 0.10$ & $0.13 \pm 0.08$ & $0.023 \pm 0.12$ \\
\hline $\begin{array}{c}\text { Amount of evaporated moisture } \\
\Omega, \mathrm{kg} \cdot \mathrm{h}^{-1}\end{array}$ & $9.7 \pm 0,10$ & $11.1 \pm 0.10$ & $10.0 \pm 0.08$ & $14.9 \pm 0.11$ \\
\hline $\begin{array}{l}\text { Actual heat consumption } q_{a} \text {, } \\
\qquad \mathrm{MJ} \cdot \mathrm{kg}^{-1}\end{array}$ & $3.5 \pm 0.07$ & $3.79 \pm 0.08$ & $3.43 \pm 0.07$ & $3.12 \pm 0.06$ \\
\hline $\begin{array}{l}\text { Lead to heat consumption } q_{l} \text {, } \\
\mathrm{MJ} \cdot \mathrm{kg}^{-1}\end{array}$ & $4.76 \pm 0.09$ & $5.34 \pm 0.07$ & $5.50 \pm 0.07$ & $6.87 \pm 0.07$ \\
\hline $\begin{array}{l}\text { Integral energy consumption } \\
q_{\text {i.e. }}, \mathrm{MJ} \cdot \mathrm{kg}^{-1}\end{array}$ & $5.73 \pm 0.09$ & $6.40 \pm 0.07$ & $6.45 \pm 0.07$ & $7.74 \pm 0.07$ \\
\hline
\end{tabular}

The results of laboratory studies showed that the seeds obtained using the new method of drying on the new dryer had high quality indicators. Germination of rye seeds and germination of wheat seeds were: $98 \% \pm 0.55$ and $98 \% \pm 0.58$; rye seeds, respectively: $99 \% \pm 0.47$ and $99 \% \pm 0.75$. These figures comply with the requirements for germination to the original and elite changes according to GOST R52325-2005. This is probably due to the fact that the new method of drying on US- 0.35 made it possible not to disrupt the integrity of the seed and its embryo due to the careful heating of the seed material at the first stage of the drying process, which contributed to accurate opening of a large number of capillaries inside the caryopsis without cracking and warping [15]. In addition, the temperature of the drying agent in the second stage of drying did not exceed $40^{\circ} \mathrm{C}$, which excluded denaturation of proteins of the caryopsis. The reversal of the direction of movement of the drying agent in the middle of drying made it possible to obtain a uniform moisture content of the drying material along the layer height in the dryer without unnecessary transshipments. Drying in a motionless layer allowed to reduce traumatizing seeds to a minimum. A gradual decrease in the temperature of the drying agent in the third stage made it possible to eliminate the penetration of the drying zone deep into the caryopsis due to the equalization of the rates of evaporation and the supply of moisture to its surface. As a result, the moisture inside the caryopsis moved exclusively in liquid form, which facilitated the delivery of nutrients to the embryo. Unloading the material after drying due to the energy of the moving air allowed to reduce injury to the seed material.

\section{Conclusions}

1. Introduction of a new drying method for US- 0.35 will reduce the energy consumption for the drying process: seed lots of wheat to $20 \%$; chopped clover grass mass up to $30 \%$; lumber timber up to $48 \%$.

2. Seed material was obtained that meets the requirements for original and elite seeds according to GOST R 52325-2005.

3. The potential is provided to increase the annual load of the drying park with the possibility of drying various materials on US-0.35.

\section{References}

[1] Marek Markowski, Wojciech Sobieski. Drying Characteristics of Barley Grain Dried in a Spouted-Bed and Combined IR-Convection Dryers. Drying Technology: An International Journal, Dec 2007, pp. 1621-1632. doi: 10.1080/0737393070159071510. 
[2] Nataliya Tsyvenkova, Inna Nezdvetskay. Results of laboratory studies of grain drying in fluidized bed dryer. International Scientific Conference Engineering for Rural Development, Latvia University of Agriculture, Jelgava, 2018, pp. 1644-1652. doi: 10.22616/ERDev2018.17.N040.

[3] Mohamed Hemisa, Ruplal Choudhary. A coupled mathematical model for simultaneous microwave and convective drying of wheat seeds. Biosystems Engineering, №112 (2012) pp. 202209.

[4] Tatjana Rubina, Aivars Aboltins. Potatoes drying dynamics research. International Scientific Conference Engineering for Rural Development, Latvia University of Agriculture, Jelgava, 2016, pp. $187-192$.

[5] Aivars Aboltins, Andris Upitis. Experimental and theoretical investigation of agricultural material drying process. International Scientific Conference Engineering for Rural Development, Latvia University of Agriculture, Jelgava, 2012, pp. 93-98.

[6] Pavel Kic, Aivars Aboltins. Drying process of two special plants. International Scientific Conference Engineering for Rural Development, Latvia University of Agriculture, Jelgava, 2014, pp. 137-142.

[7] Zivile Volkaviciute, Algirdas Raila. Drying research in perennial mugwort (ARTEMISIA DUBIA WALL.). International Scientific Conference Engineering for Rural Development, Latvia University of Agriculture, Jelgava, 2015, pp. 168-173.

[8] Дианов Л.В., Ключников А.С. Способ эффективной, низкотемпературной, конвективной сушки (Method for efficient, low-temperature, convective drying). Patent No 2654768, May 22, 2018. (In Russian).

[9] Дианов Л.В., Ключников А.С. Аэрожёлоб универсальный с автоматизированным управлением. (Universal air-saving airbag with automated control). Patent No 2648176, March 22, 2018. (In Russian).

[10]Ключников А.С. Определение производительности модулей нового универсального сушильного агрегата (Determination of the performance of new universal dryer modules). Agricultural machinery and technology: Сельскохозяйственные машины и технологии, 2018, No12(5), pp. 44-48. doi: 10.22314/2073-7599-2018-12-5-44-48. (In Russian).

[11]Лыков А.В. Теория Сушки (Theory of drying). М .: Energiya: Энергия, 1968, 469 p. (In Russian).

[12]Валушис В.Ю. Основы высокотемпературной сушки кормов (Basics of high-temperature drying of feed). М .: Kolos: Колос, 1977, 304 p. (In Russian);

[13] Малин Н.И. Энергосберегающая сушка зерна (Energy-saving grain drying). - KoloS: КолоС, 2004, 240 p. (In Russian).

[14]Дианов Л.В., Маслов М.М. Энергосберегающая, прогрессивная технология производства искусственно высушенных травяных кормов (Energy-saving, progressive technology for the production of artificially dried herbal feeds). - Yaroslavl: Ярославль: Yaroslavl State Agricultural Academy, 2007. 142 p. (In Russian)

[15] Карпов П.А. Уборка обработка и хранение семян (Cleaning, processing and storage of seeds). - M.: ROSSEL'KHOZIZDAT: РОССЕЛЬХОЗИЗДАТ, 1974, 217 p. (In Russian). 